Article

\title{
Sustaining a Korean Traditional Rural Landscape in the Context of Cultural Landscape
}

\section{Hae-Joon Jung ${ }^{1}$ and Je-Hun Ryu ${ }^{2, *}$}

1 Department of Landscape, University of Sheffield, The Arts Tower, Western Bank, Sheffield, South Yorkshire S10 2TN, UK; E-Mail: hj.jung@sheffield.ac.uk or lucidgardener@gmail.com

2 Department of Geography, Korea National University of Education, Gangnae-myeon, Heungdeok-gu, Cheongju-si, Chungbuk 28173, Korea

* Author to whom correspondence should be addressed; E-Mail: jhryu@knue.ac.kr; Tel.: +82-(0)43-230-3508.

Academic Editor: Marc A. Rosen

Received: 15 May 2015 / Accepted: 12 August 2015 / Published: 14 August 2015

\begin{abstract}
Traditional rural landscapes emerged from the long term interaction of the natural and anthropogenic environment. These landscapes are now threatened by drastic social-ecological changes. Recent international trends on sustaining cultural landscapes place great emphasis on understanding of multiple values, presented in the landscape, by considering various stakeholder perspectives. It is now recognized that strong community engagement with the landscape should be translated into conservation and management practices. This paper aims to examine the recent conservation activities around endangered traditional rural landscapes in Korea through a case study of Gacheon village. In this village, since 2000, a series of central administrative measures have been implemented to revive the local community, and to conserve its distinctive landscape. By analyzing challenges to the site, by discussing conservation experience and lessons, and by recommending future strategies for sustaining its cultural landscapes, this paper is expected to provide a basis for future policy-making for safeguarding traditional rural landscapes.
\end{abstract}

Keywords: rural landscape; rice terraces; cultural landscape; landscape conservation; community engagement 


\section{Introduction}

Rural landscapes appear as a great diversity of cultural landscapes. They are significant witnesses of the interaction between the natural and anthropogenic environment, as well as between the past and present [1]. They have continued to evolve in combination with natural and cultural factors, such as the skills, knowledge, and technologies which allowed a sustainable extraction of a wide diversity of ecosystem services and social systems $[2,3]$. The complex long term interactions of the socio-cultural and landscape factors resulted in strong embeddedness in the landscape and a landscape identity [4]. Over the past few decades, however, concern about disappearing traditional landscapes and new emerging landscapes has become a serious issue in both advanced and developing countries. The dramatic change of traditional cultural landscapes threatens several values including species, habitats, knowledge types, and landscape identities [5,6]. In the face of significant challenges to rural societies, such as abandonment of the land, intensification of agriculture, demographic changes, loss of traditional and local knowledge, pressure of urban development, and climate change [7], traditional rural landscapes also attract worldwide interest in their multifunctionality as resources for the protection of ecological and cultural diversity $[4,8,9]$. In this context, increasing attention is being paid to how these tangible and intangible values of rural landscapes can be understood, protected, and enhanced in multi-disciplinary and inter-sectoral ways [2,10,11].

In Korea, there has been an increasing demand for cultural ecosystem services since the late 1990s, in particular, since the implementation of a local self-governing system in 1995 and the economic crisis in 1997. These changes fostered a noticeable demand for re-appraising declining traditional rural landscapes as living cultural heritage. Such a re-appraisal places stronger emphasis on their utilization, and sheds new light on these landscapes as prominent symbols of local identity and tourism resources for local economies. In order to revitalize and conserve these new emerging landscape resources, the Korean government has employed administrative and legal mechanisms. These mechanisms, however, were limited to temporary economic support and had expert-driven legal restrictions which tended to cause conflict between stakeholders.

These issues have already been discussed under the international conservation categories of protected landscapes: UNESCO's World Heritage Cultural Landscape, IUCN's Category V Protected Landscapes/Seascapes, FAO's GIAHS (Globally Important Agricultural Heritage Systems) [12-18]. As unprecedented natural resource depletion and environmental destruction have become the most serious challenges, the category of cultural landscape has emerged as a key guideline that proposes alternative ways of using natural resources sustainably [19-22]. Cultural landscapes have been regarded as tangible bearers of ancient social values. They contain abundant information concerning the history of the local community and land management [23]. Cultural landscapes often reflect specific techniques of sustainable land-use which also include spiritual connections with the landscape [16]. The traditional local knowledge is rich, being accumulated over generations of direct experience with the landscape [24]. In that context, the sustainability argument reinforces the view that the historic environment should no longer be perceived in limited cultural terms, only for its archaeological, architectural, and historic interest [25]. Hence, landscapes do not need to be monumental or rare in order to mediate between the natural and the social [26]. That is why cultural landscapes, such as the traditional rural landscapes, have to be restored and re-evaluated as a way of diversifying our living environment, and creating new ones. 
The main goal of this paper is to examine the recent conservation activities around endangered traditional rural landscapes in Korea through a case study of Gacheon village. In this village, since 2000, series of central and local administrative measures have been implemented to revive the local community and to conserve its distinctive landscape. More specifically, this research addresses the following points: (i) analyzing challenges to the site; (ii) discussing conservation experience and lessons; and (iii) recommending future strategies for sustaining its cultural landscapes with the local community. These points are expected to provide a basis for future policy-making for conserving traditional rural landscapes.

\subsection{Study Area}

Gacheon village is located on the southernmost part of the Korean Peninsula in Namhae County, South Gyeonsang Province. The annual average temperature is 14.3-degree Celsius, with warm winters and cool summers. The precipitation in the region is $1820 \mathrm{~mm}$, which is the highest level in the country. All of these natural elements provide the optimal conditions for rice farming. Rice terraces surrounding the village are formed on a steep slope toward the ocean at the southeast ridge. The wide open sea to the front is deep and has a mountainous coastline, lacking the possibility for creating ports. Steep mountainous areas surrounding the village lead to the absence of other farmland and villages within a $4 \mathrm{~km}$ radius. The village is bordered by Seolheulsan Mountain $(481 \mathrm{~m})$ in the east, Eungbongsan Mountain $(421 \mathrm{~m})$ in the west, and the ridge connecting the two mountains in the north, facing Sochido Island in the Pacific in the south. According to feng-shui theory, the villagers believed their living place is located in hyeol, or a Geomancy Cave, where vital energy, or chi, flowing through the earth, is concentrated and accessible. It encourages the villagers to think they live in a more sacred and auspicious place (see Figure 1).

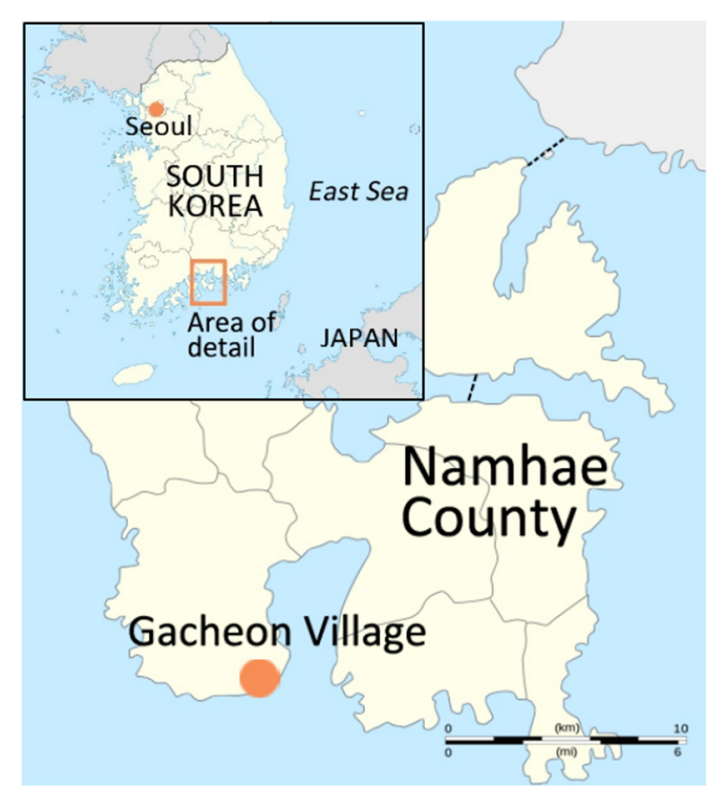

(a)

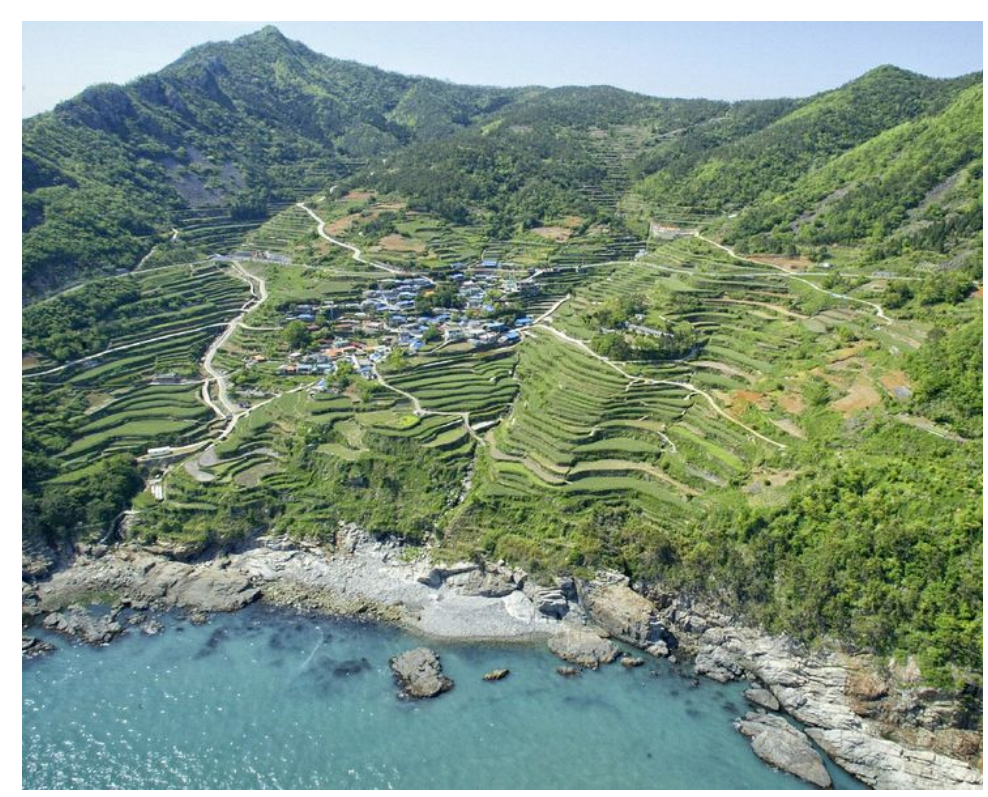

(b)

Figure 1. (a) Map of Namhae County and location of Gacheon village; (b) An aerial view of Gacheon village and rice terraces. (source: South Gyeongsang Province, Pinterest, [27].) 
There are no exact records on the origin of Gacheon village. Based on the records by the Gimhae Kim Lineage and Haman Jo Lineage, who have lived here from generation to generation, however, it is estimated that the village had started during the reign of King Sinmoon (reign from 681-692) of the Silla Kingdom. There is also a legend of Maitreya, which is believed to be responsible for rice cultivation, in relation to the six rocks at the foot of the mountains. These rocks mark the spots where six Buddhas attained salvation, and thus indicate that life here began before the Goryeo Dynasty (918-1392). Indeed, according to the beacon mound on Seolheulsan Mountain, which was supposedly used during the Japanese invasion of Korea in 1592, there was a large settlement here at least 400 years ago [28]. As people converted most of the gentle slope areas into rice-paddy in establishing the village, so as to secure as much broad farmland as possible, housing areas were shoved to the sides of hilly land (with a slope of 40 degrees). The houses were small in size with a narrow yard, fenced with stone walls in the shape of the bank around the rice terraces. For a long time the houses have been shaped, one at a time, along with the topographical conditions, and so the village shape is also irregular [29] (see Figure 2).

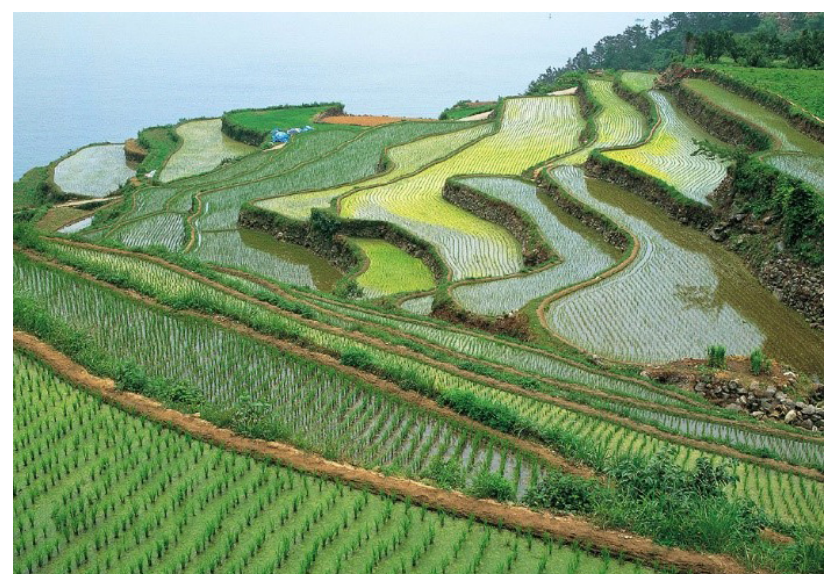

(a)

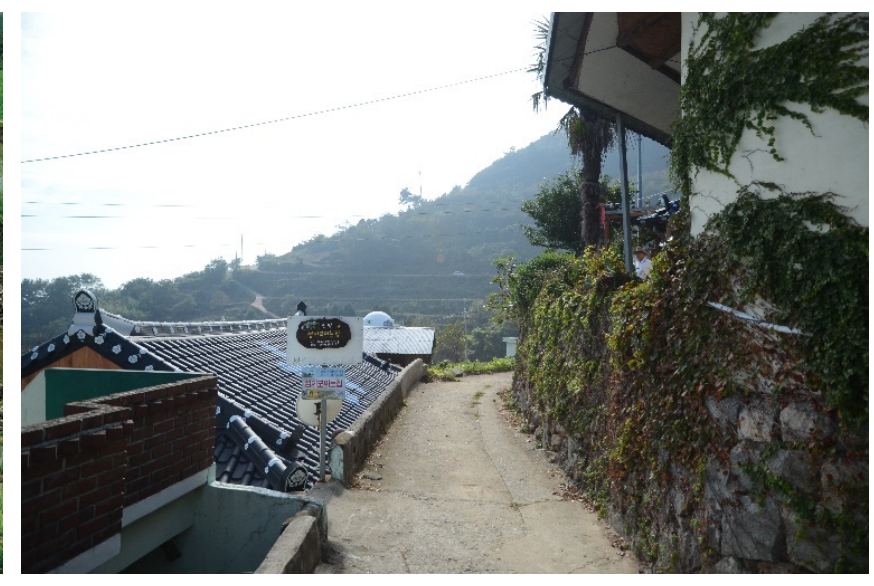

(b)

Figure 2. (a) Rice terraces of Gacheon village in the spring; (b) An alley between houses in the village.

\subsection{Methods}

Both secondary data from literature in relation to rice terraces and their protection system, and original data, which were obtained through in-depth interviews with central and local government officials, conservationists and local residents, were utilized in the research. Policy papers and reports from central and local governments, such as the Cultural Heritage Administration of Korea, the Ministry of Agriculture, Food, and Rural Affairs, and Namhae County Office, were collected to examine the national and municipal administrative measures of rice terrace conservation. Research papers in Korean were retrieved from the Research Information Sharing Service (RISS, available at http://www.riss.kr/), and English journals were collected through Elsevier (available at www.sciencedirect.com). Issues and local initiatives in relation to the conservation activities on rice terraces could be learned about from the interviews.

The historical background and policy projects for conserving and revitalizing rice terraces in Gacheon village were summarized in accord with interviews with local stakeholders. Interviews with individuals 
have provided important empirical data. Based on the semi-structured questionnaire, three rounds of in-depth interviews were conducted with key stakeholders of the village; seven local residents in 2011, 2012, and 2013, which include the chairperson of Daraengi Farm Agricultural Association Corporation, and the head of the Rice Terrace Conservation Society. Three public officers of the Cultural Heritage Administration of Korea (CHA) and two public officers of the Namhae County, which are the central and local government side respectively, were interviewed in 2011. The interviews provided important evidence, particularly in aiding understanding present-day values with respect to the village and rice terraces, and the changing social atmospheres and safeguarding policies concerning the site. The main method for analysis was mapping: each interview was examined separately first, and then in relation to the others, as all the interviewees have different experience or have worked in different fields. The material was then correlated with related issues and events described in the various other sources.

\section{Results}

\subsection{The Multiple Values of the Rice Terraces of Gacheon Village}

Rice, oryza sativa, is one of the most important crops in Korean history. Because rice was regarded as a sacred crop, which was able to communicate with the human spirit, Koreans believed that rice was the best among the crops [30]. Korea is a mountainous country, 70 percent of whose territory is covered with mountains, so most living places are surrounded by high and low mountains. Before cities developed, the life cycles of Koreans revolved around mountains. Due to mountainous topographical conditions, there were many rice terraces which used the slope of the mountains. When those slopes with a minimum of seven degrees are taken as rice terraces, they add up to 270,000 ha, accounting for approximately 18 percent of the total of rice paddies in the country, 1,630,000 ha [31].

Over 400 irregularly shaped rice paddies lie almost everywhere in Gacheon village, making up about 100 terraces which curve along with the steep slope. The highest terrace is built in the range of 250-300 m above sea level; most of them are of wide distribution at the range of 50-100 m, like the village itself. There are different types of rice paddies, from a Satgat (Korean traditional hat made of bamboo) parcel of rice paddy, so named because a parcel is small enough to be covered by the Satgat hat, to larger than $1000 \mathrm{~m}^{2}$. Ridges between the rice terraces were built up on steep incline by piling up fine stones. The stones were collected in the mountain behind the village. Huge pieces of stones have continued to be weathered and are still present as a depositional landform on the slope behind the village [32]. The stonework is piled up as vertically as possible to secure a little more area for the cultivation of rice. The rice paddies are built in terraces in order to make a flat rice paddy which can store water above the curved stonework. Due to the topographical limitations, it was hard to anchor a ship on the seashore in front of the village, and thus the villagers depended solely on traditional agricultural techniques such as ploughing. In the past, all 400 parcels of rice paddy had a distinguishing name, which suggests that the villagers formed a close relationship with their rice terraces [33]. These rice terraces embody traditional life of the community and have been in harmony with the surrounding mountain and the wide open sea to the fore, combining in a distinctively traditional and natural landscape.

In Gacheon village, there are abundant intangible cultural heritages in relation to agriculture. Agricultural society, in general, places the emphasis on fecundity and abundance, while expressing 
sexual aspects of religious belief. There are female and male rocks that represent the sexual aspects. Namhae Gacheon female and male rocks, designated as a Folk Cultural Property of South Gyeongsang Province, are located at the bottom of the village, standing beside each other. The female rock resembles a pregnant woman lying obliquely, while the male rocks rise up in the shape of his sexual organs. The rocks are also called Maitreya: female and male Maitreya respectively. They were first found by Jo Gwang-Jin, who was appointed as the governor of Namhae County in 1751. It is said that an elderly man appeared in his dream and gave him a revelation [26,32]. A legend says that if a woman prayed under the male Maitreya without anyone knowing, she could beget a son. Women who hoped to become pregnant from the village as well as from elsewhere visited to pray (extracted from an interview with a local resident in 2011). On full-moon day in October by the lunar calendar, the villagers pay their respects to the village spirit with a ritual, in order to pray for a good harvest and big catches. The master of the village ritual must be clean, both mentally and physically. Moreover, it begins with replacing the old red clay in the "rice grave" with freshly collected clay from uncontaminated spots on the mountain behind the village. There are three rice graves, located in the centre, east, and west of the village. During the ritual the village spirits are provided with various foods that have been prepared from the newly harvested crop of grain from the rice terraces as well as fruit and fish. The key feature of the ritual is the burial of cooked rice at these three graves. To complete the ritual, the villagers burn papers with a wish written on them, and let them fly in the air. After this ritual, the festival begins, playing nongak (traditional Korean music performance) and jwibulnori (burning of dry grass on the ridges between rice fields to exterminate harmful insects and enrich the soil of the rice paddies) (extracted from an interview with a local resident in 2012) (see Figure 3).

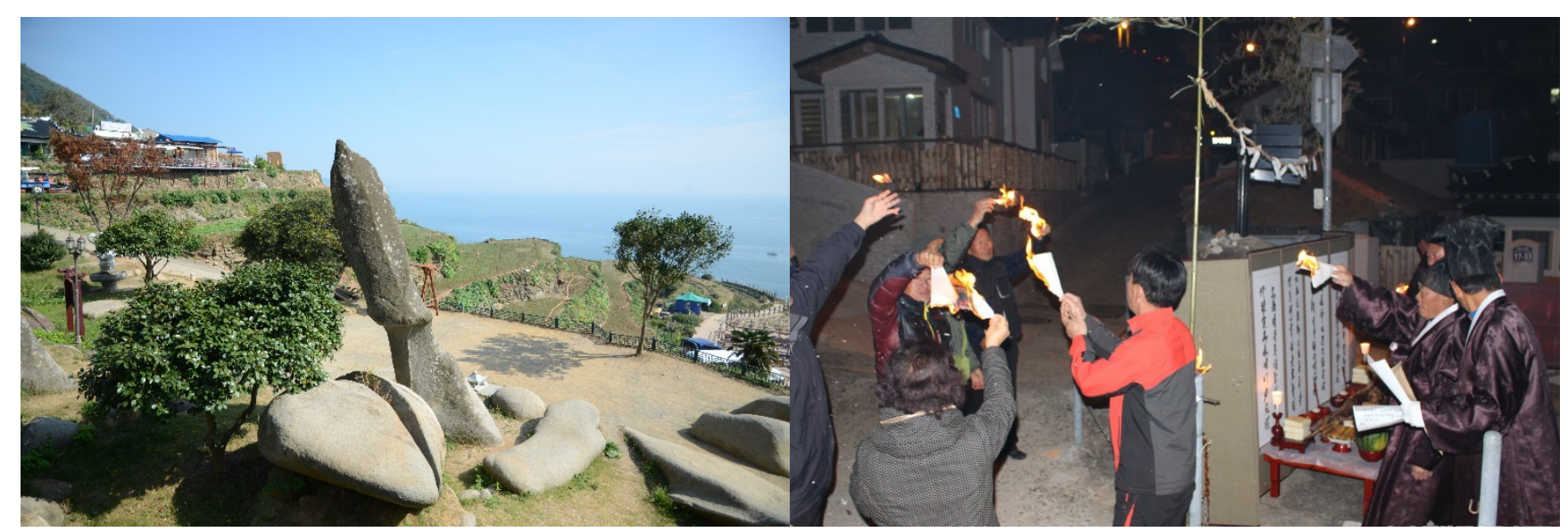

(a)

(b)

Figure 3. (a) Female and male rocks; (b) Burning paper written with villagers' wishes after the village ritual.

The rice terraces have been highly appreciated as a testimony of traditional agriculture and social custom, and are regarded as a representative cultural landscape, interwoven with the natural environment and the enormous efforts of the residents. In the 21 th century, the rice terraces have attracted a lot of attention from domestic and foreign scholars on cultural diversity because they not only produce a staple food, but also have multifunctional aspects in connection with our life. They have relatively low 
productivity of rice when compared to flat land, but rice terraces still play a significant role in production, when considering future food supply issues. Rice paddies on the slope combine the functions of maintaining and storing the flow of rain water, and act as small dams that not only suppress but also retain water in the event of a sudden flow of water. The shape of rice terraces can also be used to stop soil erosion by controlling the water flow, and the ridges between the terraces help to prevent soil loss. Nature-friendly rice terraces provide a habitat with a variety of ecosystems, including those of microorganisms and insects, and play a key role in sustaining them. The terrace purifies the air in which the rice grows, while absorbing carbon dioxide and emitting oxygen (according to the Rural Development Administration of Korea, annually released oxygen from rice paddies in Korea is estimated at about 10,190 thousand tons), and lowering the ambient temperature by evaporating heat. The aesthetic value of the rice terraces is outstanding as compared to the flat ones, and they bring amenity values such as transmission of community, culture, education, and sightseeing [7,33,34].

\subsection{Conservation Issues and Discussion}

Greater attention to traditional landscape in the 21 st century has brought about increasing awareness of the aesthetic value of rice terraces, which have been highly appreciated as maintaining traditional agricultural and social customs [7]. Rice terraces have played a significant role in agriculture, while providing amenity resources that extend urban-rural interchange and the vitalization of Gacheon village in relation to the regional economy. There has been no doubt amongst the central government, experts, and local residents that the conservation of rice terraces brings great benefits to the community and the nation as well as the next generation. Efforts have been continued to facilitate the authorities in devising proper conservation and revitalization measures since 2000 (see Table 1). However, at this moment, this traditional rural landscape faces constant and unavoidable threats from the following issues: changing population and agricultural systems, tourism, and landscape heritage designation.

Table 1. Institutional approaches to promoting and protecting landscapes of rice terraces in Gacheon village.

\begin{tabular}{|c|c|c|c|}
\hline Years & Events & Institutions & Features \\
\hline 2001 & $\begin{array}{l}\text { Direct Payment } \\
\text { Program for Rice Paddy }\end{array}$ & $\begin{array}{l}\text { Implemented by the Ministry of } \\
\text { Agriculture, Food and Rural } \\
\text { Affairs (central government side) }\end{array}$ & $\begin{array}{l}\text { Promoting rice farming and } \\
\text { stabilising the incomes of } \\
\text { farmers by providing a subsidy }\end{array}$ \\
\hline 2002 & $\begin{array}{l}\text { Traditional Rural } \\
\text { Theme Village }\end{array}$ & $\begin{array}{l}\text { Selected by the Rural Development } \\
\text { Administration (central government } \\
\text { side) as a flagship project }\end{array}$ & $\begin{array}{l}\text { Promoting rural tourism by } \\
\text { governmental funds for planning a } \\
\text { tourism initiative and developing } \\
\text { related programs }\end{array}$ \\
\hline 2004 & Outstanding Eco-village & $\begin{array}{l}\text { Selected by the Ministry of } \\
\text { Environment (central } \\
\text { government side) }\end{array}$ & $\begin{array}{l}\text { Raising awareness of } \\
\text { environmental protection and } \\
\text { encouraging eco-tourism }\end{array}$ \\
\hline
\end{tabular}


Table 1. Cont.

\begin{tabular}{|c|c|c|c|}
\hline Years & Events & Institutions & Features \\
\hline \multirow{2}{*}{2005} & Scenic Site & $\begin{array}{l}\text { Designated by the Cultural } \\
\text { Heritage Administration } \\
\text { (central government side) }\end{array}$ & $\begin{array}{l}\text { Protecting landscape as } \\
\text { cultural heritage by the legal system }\end{array}$ \\
\hline & $\begin{array}{l}\text { Direct Payment Program } \\
\text { for Rural Landscape } \\
\text { Conservation }\end{array}$ & $\begin{array}{l}\text { Implemented by the Ministry } \\
\text { of Agriculture, Food, and Rural } \\
\text { Affairs (central government side) }\end{array}$ & $\begin{array}{l}\text { Beautifying rural landscapes by } \\
\text { cultivating landscape crops and } \\
\text { improving landscape elements }\end{array}$ \\
\hline \multirow[b]{2}{*}{2006} & $\begin{array}{l}\text { Green Rural } \\
\text { Tourism Village }\end{array}$ & $\begin{array}{l}\text { Selected by the Ministry of } \\
\text { Agriculture, Food, and Rural } \\
\text { Affairs (central government side) }\end{array}$ & $\begin{array}{l}\text { Promoting rural economy and } \\
\text { increasing rural quality of life } \\
\text { by developing rural tourism }\end{array}$ \\
\hline & $\begin{array}{l}\text { Making Liveable } \\
\text { Community Project }\end{array}$ & $\begin{array}{l}\text { Selected by the Ministry } \\
\text { of Government Administration } \\
\text { and Home Affairs } \\
\text { (central government side) }\end{array}$ & $\begin{array}{l}\text { Increasing quality of life and living } \\
\text { places of urban and rural areas for } \\
\text { balanced regional development }\end{array}$ \\
\hline 2007 & Landscape Act & $\begin{array}{l}\text { Enacted by the Ministry of Land, } \\
\text { Infrastructure, and Transport } \\
\text { (central government side) }\end{array}$ & $\begin{array}{l}\text { Providing a guideline for the } \\
\text { systematic landscape management } \\
\text { based on bottom-up policies }\end{array}$ \\
\hline 2007-12 & $\begin{array}{l}\text { Nationalization } \\
\text { of Rice Terraces }\end{array}$ & $\begin{array}{l}\text { Planned by the Cultural } \\
\text { Heritage Administration } \\
\text { (central government side) }\end{array}$ & $\begin{array}{l}\text { Suspended by the global } \\
\text { financial crisis in } 2008\end{array}$ \\
\hline 2008 & $\begin{array}{l}100 \text { Most Outstanding } \\
\text { Hundred Rural Amenity }\end{array}$ & $\begin{array}{l}\text { Selected by the Rural } \\
\text { Development Administration } \\
\text { (central government side) }\end{array}$ & $\begin{array}{l}\text { Cultivating and introducing potential } \\
\text { tourism resources in rural areas to } \\
\text { promote rural tourism and } \\
\text { develop their economy }\end{array}$ \\
\hline 2009 & $\begin{array}{l}\text { Model Village for the } \\
\text { Promotion of the } \\
1.5 \text { Industries }\end{array}$ & $\begin{array}{l}\text { Implemented by the } \\
\text { Namhae County in } \\
\text { cooperation (local government) }\end{array}$ & $\begin{array}{l}\text { Providing consulting service, improving } \\
\text { tourist facilities, and educating local } \\
\text { residents to innovate rural tourism }\end{array}$ \\
\hline 2010 & $\begin{array}{l}\text { Permission Standards } \\
\text { for Alteration of } \\
\text { Current State }\end{array}$ & $\begin{array}{l}\text { Declared by the Cultural Heritage } \\
\text { Administration (central } \\
\text { government side) in consultation } \\
\text { with the Namhae County } \\
\text { (local government) }\end{array}$ & $\begin{array}{l}\text { Transferring rights to the local } \\
\text { government to set Permission Standards } \\
\text { within CAHCE to avoid excessive legal } \\
\text { controls over protected area }\end{array}$ \\
\hline 2012 & $\begin{array}{l}\text { Symposium of } \\
\text { Conservation and } \\
\text { Utilization of the } \\
\text { Rice Terraces of } \\
\text { Gacheon Village' }\end{array}$ & $\begin{array}{l}\text { Hosted by the Cultural Heritage } \\
\text { Administration (central government } \\
\text { side) in cooperation with the } \\
\text { Namhae County (local government) } \\
\text { and residents of the village }\end{array}$ & $\begin{array}{l}\text { The first meeting, central and local } \\
\text { governments, experts and local residents } \\
\text { gathered at one place to discuss issues } \\
\text { after the designation of Scenic Site }\end{array}$ \\
\hline 2013 & $\begin{array}{l}\text { Conservation and } \\
\text { Management Ordinance } \\
\text { for the Rice Terraces of } \\
\text { Gacheon Village' }\end{array}$ & $\begin{array}{l}\text { Declared by the Namhae County } \\
\text { (local government) in cooperation } \\
\text { with residents of the village }\end{array}$ & $\begin{array}{l}\text { Establishing the Rice Terrace } \\
\text { Conservation Society to } \\
\text { build a cooperative system } \\
\text { between stakeholders }\end{array}$ \\
\hline
\end{tabular}




\subsubsection{Changing Population and Agricultural System}

The reduction in income from rice paddy agriculture has resulted from a number of factors: the inefficiency of productivity of the labour to maintain them, together with a decrease in population arising from the backward conditions of the living environment and urbanization; and the reduction in the price of rice caused by opening the market to imports from 1995, which was aggravated by the change in people's diet to the processed food and the adoption of westernized eating habits. Moreover, the government selectively supported projects focused on efficient agriculture, which discouraged farmers cultivating paddy fields that were restricted by topographical conditions such as rice terraces. For these reasons, the average rural household income was only 66.8 percent of its urban counterpart in 2010, and continued to decrease with the ever-increasing working expenses of farm management. Even worse, 23.7 percent of rural households spent less than the minimum cost of the living in 2011 [35]. Such challenges accelerated the exodus of the residents from rural areas, and the rice paddies ended up with being neglected to be damaged as a consequence.

These nationwide problems and the environmental and socio-economic issues around Gacheon village itself have caused the rapid decline of rice farming, leading to the abandonment of the rice terraces and community breakdown. As it is difficult to use agricultural machines on the rice terraces of Gacheon village, people have to farm in traditional ways, relying on the power of humans and oxen alone. Facing the strong wind from the sea, their profit from farming fell short of their effort. The village shares its border with the sea, but the cliff seashore and shallow sea level preclude fishing boats from anchoring and sailing effectively. Villagers could collect marine products only by jumping into the sea, but those who could not do this had to buy seafood in a market, far away from the village. These living conditions have made the community suffer from the seafood shortage (extracted from an interview with a local resident in 2011). Consequently, the exodus of the village's population progressed rapidly from the early 80 s. At the time of the field survey in 2006 , the population was about 118 , and residents in their 60 s or older accounted for greatest proportion of the population, as in the other rural communities in Korea. The population of the village in 2014 was 175 (male: 82, female: 93), of whom males in their 50s were the highest proportion; females in their 70s were also a large percentage of the population [36]. Among the 58 households recorded in 2006, 40 were registered as rural, but of these only 19 were actually engaged in farming [37]. In the interviews conducted with local residents in 2010, it was revealed that there were only nine households engaged in farming. The reason for the gaps between the numbers recorded on the list of residents and those who actually live in the village seems to arise from outsiders who own houses or property in the village. Likewise, the population structure of the village lacks people between 30 and 50 years old who are socially active, and young people under the age of 20. This structural disequilibrium is becoming a major risk factor in the rice farming of the village (see Table 2).

Table 2. Changing population of Gacheon Village.

\begin{tabular}{ccccccccccccc}
\hline Year & $\mathbf{1 9 8 2}$ & $\mathbf{1 9 8 4}$ & $\mathbf{1 9 8 7}$ & $\mathbf{1 9 9 0}$ & $\mathbf{1 9 9 3}$ & $\mathbf{1 9 9 6}$ & $\mathbf{1 9 9 9}$ & $\mathbf{2 0 0 2}$ & $\mathbf{2 0 0 5}$ & $\mathbf{2 0 0 8}$ & $\mathbf{2 0 1 1}$ & $\mathbf{2 0 1 4}$ \\
\hline Households & 79 & 75 & 72 & 71 & 63 & 62 & 62 & 58 & 69 & 84 & 94 & 97 \\
Population & 363 & 320 & 296 & 257 & 213 & 181 & 171 & 155 & 145 & 174 & 175 & 175 \\
\hline \multicolumn{1}{c}{ Source: Namhae County Office, Annual Statistics of Namhae County, [38]. }
\end{tabular}


The farmland ratio of the village, including rice paddies and dry fields, accounted for about 31 percent in 1974, as shown in Table 3, but gradually dropped below 20 percent after 1998, declining radically below 10 percent between 2004 and 2009. It is estimated that challenges such as cultivation conditions, in which farming machinery is not available, and also a shortage of labour arising from its aging society, resulted in soaring production costs, which finally caused a rapid increase in farmlands being abandoned. The area of the rice paddies was significantly reduced to be replaced by dry fields [39]. Because dry-field farming yields more profit with a smaller workforce, local residents increasingly converted the rice paddies into dry fields. In turn, in 2012, the percentage of rice paddies made up only 7.4 percent of the whole $227,554 \mathrm{~m}^{2}$ of farm land despite the recovery of some rice terraces, and the percentage of dry fields and fallow land still accounted for 77.6 percent and 15 percent respectively [40] (see Table 3).

Table 3. The Changing Agricultural System (rice paddy and dry field) of Gacheon Village.

\begin{tabular}{|c|c|c|c|c|c|}
\hline & $1974(\%)$ & $1988(\%)$ & $1999(\%)$ & $2004(\%)$ & $2009(\%)$ \\
\hline Rice Paddy & 30.0 ha (19.2) & 26.0 ha (16.7) & 23.0 ha (14.7) & 17.0 ha (10.9) & 5.0 ha (3.2) \\
\hline Dry Field & 19.0 ha (12.2) & 14.0 ha $(9.0)$ & 21.0 ha (13.5) & 17.0 ha (10.9) & 10.0 ha (6.4) \\
\hline Other & 107.0 ha $(68.6)$ & 116.0 ha (74.3) & 112.0 ha (71.8) & 122.0 ha $(78.2)$ & 141.0 ha (90.4) \\
\hline
\end{tabular}

Source: Lee and Kim, 2011, [39].

Korean government is implementing the Direct Payment Program (DPP), which plans on farming income stabilization to curb the rural exodus. DPPs in relation to rice terraces of the village are presented in Table 4. Such programs, or rather, their ineffectiveness, harm the indigenous landscape: the Direct Payment Program for Rice Paddy (DDP for Rice Paddy) and Direct Payment Program for Rural Landscape Conservation (DDP for Rural Landscape Conservation).

Table 4. Types of Direct Payment Programs.

\begin{tabular}{|c|c|c|}
\hline Objects & Types & Contents \\
\hline $\begin{array}{l}\text { Income } \\
\text { Compensation }\end{array}$ & $\begin{array}{l}\text { Direct Payment Program } \\
\text { for Rice Paddy (2001) }\end{array}$ & $\begin{array}{l}\text { Providing a subsidy to farmers depending upon the area of } \\
\text { paddy fields (in case the rice price in the current year reduced } \\
\text { compared to the target price, } 85 \% \text { of difference would be paid) }\end{array}$ \\
\hline \multirow{3}{*}{ Multipurpose } & $\begin{array}{l}\text { Direct Payment Program for } \\
\text { Disadvantaged Areas (2004) }\end{array}$ & $\begin{array}{l}\text { Providing a subsidy to dry-fields or orchards located in } \\
\text { villages with poor quality of settlement environment } \\
\text { (farmlands or pasture on a hill with a gradient of } 14 \% \text { or more) }\end{array}$ \\
\hline & $\begin{array}{l}\text { Direct Payment Program } \\
\text { for Environment-friendly } \\
\text { Agriculture (1999) }\end{array}$ & Providing a subsidy to environment-friendly agriculture \\
\hline & $\begin{array}{l}\text { Direct Payment Program } \\
\text { for Rural Landscape } \\
\text { Conservation }(2005)\end{array}$ & $\begin{array}{l}\text { Providing a subsidy to cultivating landscape } \\
\text { crops to beautify rural landscapes }\end{array}$ \\
\hline Restructuring & $\begin{array}{l}\text { Direct Payment Program for the } \\
\text { Transfer of Farming } \\
\text { Management Right (1997) }\end{array}$ & $\begin{array}{l}\text { Providing a subsidy in case old farmers sell or } \\
\text { lease their farmlands (to stabilise income of } \\
\text { retired-farmers, and to foster full-time farmers) }\end{array}$ \\
\hline
\end{tabular}

Source: Ministry of Agriculture, Food and Rural Affairs, [41]. 
The DPP for Rice Paddy accounts for 95 percent of the whole budget of DPP. It is a government subsidy to promote public interest in the rice paddies and to encourage environmental conservation and safe agricultural production. It strongly recommends the environment-friendly farming methods of using a suitable quantity of fertilizers and agricultural pesticides. Those rice paddies that meet the requirements of the DPP for Environment-friendly Agriculture have been supported and merged into the DPP for Rice Paddy. To receive benefits from the program, one should have the area of minimum $10,000 \mathrm{~m}^{2}$. Most of the rice paddies in Gacheon village, however, are small arable plots, smaller than the standard, and thus villagers barely benefit from this program. In addition, the rice terraces of the village are rice paddies that depend solely on rainfall for water, with low soil depth. Namhae County, where the village belongs, is carrying out environmentally-friendly agriculture with using pond snails to benefit from the DPP. It is almost impossible, however, to apply this strategy to the village's rice farming system since pond snails are prone to die when there is a water shortage (extracted from an interview with a local resident in 2011). It has been possible for the area to be subsidized with low-cost pesticides, but Low Pesticides Certification is no longer authorized by the government. It is, therefore, difficult to see how the village could run its rice farming through the DPP for Rice Paddy.

Another reason for the difficulty in the restoration of the rice paddies is that local residents converted them into dry fields to cultivate certain crops in order to receive the subsidy. The DPP for Rural Landscape Conservation, implemented from 2005, is an agreement between the local government and local residents to improve and maintain the rural landscape by cultivating so-called landscape crops: rape, evening primrose, lavender, sunflower, cosmos, buckwheat and field poppy. These crops can beautify rural landscapes while bringing a subsidy for the loss of income from cultivating the landscape crops rather than conventional crops such as rice (see Figure 4a). Given the fact that the increasingly abandoned arable lands are lowering the quality of the rural environment and the landscape, the government has introduced its programs so as to meet urbanites' increasing demand for leisure activities, and to promote the vitalization of rural communities [2].

However, instead of taking on the protection of the wildlife habitat and management of streams and the seaside, local residents were inclined only to pursue personal benefits to them. They asked the local government to buy the landscape crops they planted on rice terraces [42]. To receive a benefit of 1700 thousand KRW (1500 USD) per 10,000 $\mathrm{m}^{2}$ from the program, they had to plant and cultivate dry-field crops on the rice terraces. This brought about the side-effect that the traditional seasonal landscape that had been created by the paddy fields was radically changed (See Figure 4b). Rice fields are vulnerable on the abandonment of rice production. The soil reacts chemically with the inflowing water and thus maintains stonework and the shape of the rice terraces. If people cultivate dry-field crops in the fields, instead of rice with water irrigation, the stonework supporting the terraces may fall, while damaging the distinctive landscapes of rice terraces. The change has a damaging effect on tourism; after looking around the area, numerous tourists have asked where the rice terraces are (extracted from an interview with a local resident in 2011). Considering the problems, the village made an effort to revive the rice terraces in 2012, but the restored ones constituted only about $2000 \mathrm{~m}^{2}$. 


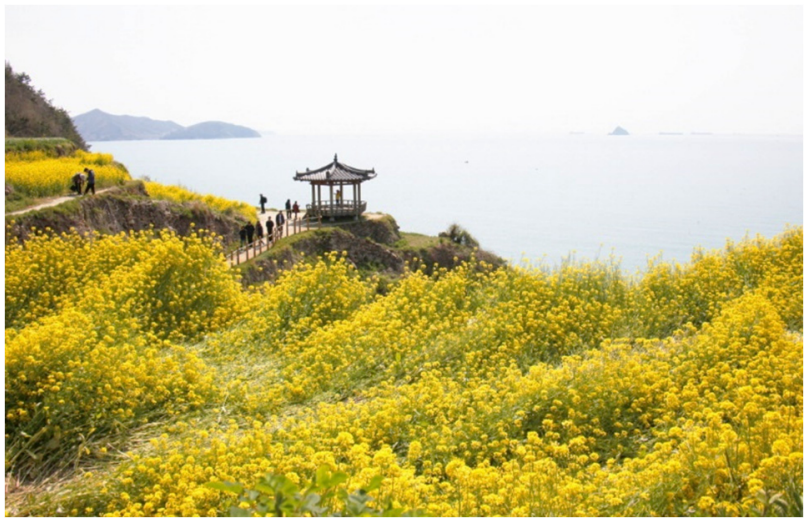

(a)

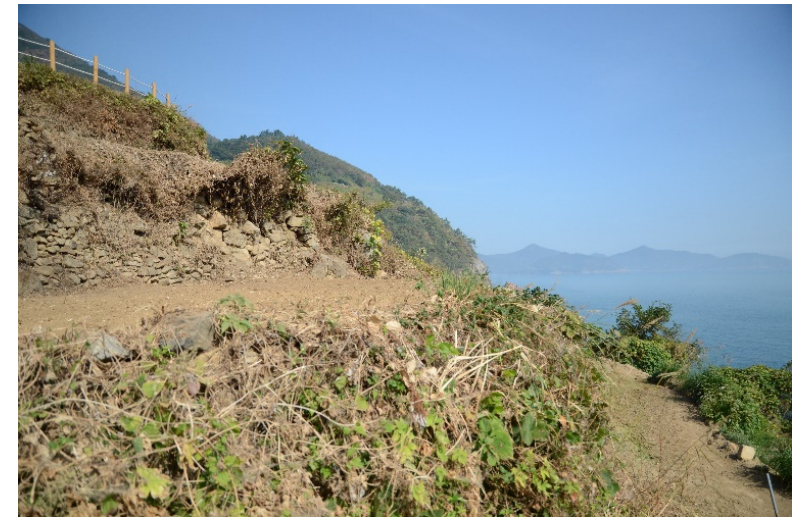

(b)

Figure 4. (a) Spring landscape of the village filled with rape flower; (b) Collapsing rice terraces.

\subsubsection{Tourism}

After the economic crisis in 1997, the traditional extended family system has been breaking up in favour of the nuclear family, and individualistic tendencies have accelerated. Since the five-day week system was introduced in July 2004, such a social atmosphere, together with improved living standards, has brought about an increase in the level of domestic tourism. As a result, the rural landscape has rapidly become a major tourism resource, and subsequent inappropriate development has changed the landscape into a pleasure resort for urban residents. The rural landscape and community has gradually lost its former owners and undergone transformations including intensive agriculture, environmental contamination, and ecological dilapidation [43]. This means that the social demand for new features in the rural landscape is a source of radical change and variation. Among the landscapes that have been built up slowly over thousands of years, even highly valuable landscapes have disappeared or been transformed into an entirely different form in only a few years.

As a result of the Traditional Rural Theme Village project in 2002, implemented by the Rural Development Administration, Gacheon village and rice terraces emerged as new major tourism resources. Although a number of mountain climbers, anglers, and worshippers of Maitreya had visited the vicinity, their visits did not directly lead to income for the village. As the size of the rice paddies decreased from $220,000 \mathrm{~m}^{2}$ to $70,000 \mathrm{~m}^{2}$, traditional farming alone is not profitable anymore. In order to reform this income structure, the Rural Development Administration spent 200 million KRW (190 thousand USD). The support fund allowed them to plan on a tourism initiative and to develop related programs for improving awareness of the village, while increasing the revenue from tourism [44]. As the village had become nationally known through the project, the number of visitors and farming income sharply increased. Between 2002 and 2005 visitors increased in number from 2010 to 28,890, a fourteen-fold increase, and the project income swelled about nine times from 33 million KRW (30 thousand USD) to 289 million KRW (270 thousand USD) [45]. Moreover, the opening of the bridge connecting Namhae County with Sacheon County, shortened travel time by replacing a waterway to improve accessibility of the village. A plan for the Special Local Development Zone, introduced by the central government, also made a significant contribution to the village as a tourist attraction. The Special Local Development Zone was modelled after the Special Zone for 
Structural Reform in Japan. It is a specialized project to promote the local economy. The government selects competitive and promising businesses and lifts regulations on them [46]. As a result of the deregulation by the government, Namhae County was able to develop the Special Tourist Zone for Ecology Experience with Gacheon village as its centre. The designation as a Scenic Site also contributed to the increase in the value of village. In 2008, the village was selected for the Model Village for the Promotion of the 1.5 Industries by the Ministry of Culture, Sports, and Tourism. The Ministry granted a billion KRW (930 thousand USD) to develop the tourism package, which was directly connected to boosting the residents' income.

The villagers did not voluntarily intend to develop their living areas into tourism resources from the beginning. Because the rice terraces were the only means of making a livelihood, they did not recognize their landscape value. It was only after 2002 that they began to look closely at the village they had lived in (extracted from an interview with a local resident in 2011). The village itself has made an effort to attract tourists since then. An autonomous local society of the village holds a month-long Rice Planting Festival in June of every year. The festival includes various rural activities and art performances such as folk songs and a prayer ceremony for a good harvest, which attracts tourists who are interested in the customs of the traditional agricultural society. It has been recognized as the most successful regional festival because around 20,000 tourists had visited the first festival. The society uses 10 percent of the fund from the festival as a common fund that it reinvests in maintenance fees and more convenient facilities in the village. With this success, 180,000 tourists visited the village in 2010, and the villagers were able to raise 490 million KRW (455 thousand USD) of non-farm income through stays on farms and the sale of agricultural products. There were 230,000 tourists in 2008, but there were only 200,000 people visiting in 2009 because of the swine flu. Tourism revenue increased to $450 \mathrm{KRW}$ (418 thousand USD). Due to an increase in the number of tourists and income, annual income per household amounted to about two million won in 2000, and at the present time it has increased more than tenfold.

The growth of tourism brought a changed awareness to the younger generation of the village; the rice terraces were landscape that was symbolic of the diligence and hard work of their parents' generation, and, at the same time, representative of poverty (extracted from an interview with a local resident in 2011). As compared to their parents' generation, they lacked attachment to the rice paddies, and exploited them for other more commercial uses than growing rice. For instance, they planted lucrative crops or created recreational facilities and private residences to accommodate tourists. There are 16 households running bed and breakfast businesses, and 12 households opening their houses to tourists during the holiday season to earn non-farm income. Although the village is one of the most famous traditional villages in Korea, which attracts more than 200,000 visits each year, only about 7 percent of the tourists spent a night in the village, and most of them looked around for an hour or make a day trip. It is estimated that the average tourist expenditure is only about $4200 \mathrm{KRW}$ (4 USD), which is quite low. By virtue of the increasing number of lavish private hotels, tourists using the accommodation in the village itself have been on the wane, except during the summer peak season [47]. This kind of private hotel, which attracts a huge influx of outsiders, is run by large enterprises these days. An associated problem is that large enterprise hotels spring up almost everywhere along the coastal roads, without thinking about the environment and local communities, while destroying the natural landscape and creating conflict with the local community. In Namhae County, in which there are only 20,000 households, there 
were 877 (4.3 percent) private residences that temporarily took lodgings in 2012 . It was said that only 10 percent of them were run by the actual residents [48]. Above all, as the village became a famous tourist attraction, the investments that were raised from outside increased the price of the land in the village (see Table 5). As a result, the inhabitants began to sell their property to outsiders who remodelled the recreational facilities or converted the rice paddies to fields for profitable farm products rather than traditional rice farming (extracted from an interview with a local resident in 2013).

Table 5. Changing officially assessed land price of Gacheon Village $\left(\mathrm{KRW} / \mathrm{m}^{2}\right)$.

\begin{tabular}{ccccccccccc}
\hline \multicolumn{1}{c}{ Address * } & & $\mathbf{1 9 9 0}$ & $\mathbf{1 9 9 3}$ & $\mathbf{1 9 9 6}$ & $\mathbf{1 9 9 9}$ & $\mathbf{2 0 0 2}$ & $\mathbf{2 0 0 5}$ & $\mathbf{2 0 0 8}$ & $\mathbf{2 0 1 1}$ & $\mathbf{2 0 1 4}$ \\
\hline \multirow{2}{*}{ Designated Area } & 762 & 1200 & 1190 & 996 & 1410 & 1780 & 3760 & 5180 & 6720 & 11,300 \\
& 905 & 1500 & 1050 & 2180 & 1450 & 1840 & 3880 & 5230 & 6790 & 11,500 \\
\hline Non-designated & 899 & 3000 & 3290 & 3310 & 3510 & 4500 & 16,100 & 22,900 & 27,200 & 43,500 \\
residential Area & 937 & 3000 & 3080 & 2750 & 3510 & 4500 & 15,300 & 18,700 & 22,200 & 35,500 \\
\hline
\end{tabular}

Source: South Gyeongsang Province Office, Gyeongnam Real Estate Information System, [49].

* The areas are categorized into Designated and Non-designated Area of Scenic Sites, activated in 2005.

The local government pushed the project forward actively, but the lack of agreement among the local community triggered negative effects on the village in terms of loss of identity. The authority adopted other regions' popular rural tourism programs inappropriately to modernize traditional housing structures, such as roofs with modern ingredients which did not correspond with local usage. It also implemented the Village Landscape Remodelling Project to draw huge mural paintings on the walls or the roofs, while damaging the distinctive regional style and the authenticity of the area's rural landscape.

The massive surge of tourists has damaged the very environmental and cultural resources which had contributed to the village as a famous tourist attraction. Restaurants, which were built up along the major roads in the village, are also inharmonious in relation to the surrounding landscape, and the thoughtless behaviour of a few tourists, as well as their traffic congestion, break the village's tranquillity, especially during the weekend. Although the economic conditions of the village have improved, the local community is very concerned that their peaceful living place might change into a tourist attraction with sales gimmicks. When it comes to the conservation and development of the village, there have been frequent conflicts between the young and the old. The conflict is also found between the people who rely on tourism revenue by running bed and breakfast or experience programs, and the others who still work at and value traditional agriculture (extracted from an interview with local residents in 2011).

\subsubsection{Landscape Heritage Designation}

To conserve the values of the past in landscape, many countries have introduced statutory landscape designations of national or local heritage. These designations deal with places to which cultural significance has been ascribed, while largely reflecting post-enlightenment European intellectual traditions [11]. Yet in other nations that have undergone modernization, traditional culture has been seen as an essential element to promote social integration as the foundation of the national agenda. A culture vanishes if it is neglected; state intervention is required to some extent to guarantee the public the right to enjoy their cultural traditions [50]. One of the policies which require state intervention aims to retain national identity, both tangibly and intangibly, through protection of cultural heritage. To conserve and 
protect Korean traditional landscapes, the Korean government have enacted one type of landscape designation in national heritage policy, namely, the Scenic Site, or Myeongseug in Korean. It was implemented under the Cultural Properties Protection Act (CPPA) in 1962. Since 2000, the concept of Scenic Sites has stretched only from their being "a picturesque place" to also include "traditional industrial landscapes" which were created by people [51]. Local governments with Scenic Sites in their administrative district want to utilize their image and actual landscapes to represent local identity [52]. But there is an increasing social demand to use the Scenic Sites as "a leisure place".

Scenic sites are labelled as state-designated cultural heritage, and management matters in relation to them follow the CPPA. Administration on cultural heritage, such as designation, cancellation, conservation, management, and utilization, follows the Cultural Heritage Charter (1997). The Charter asks citizens to protect and conserve cultural heritage so that it can be passed on to future generations, and to put effort into preventing damage and destruction of the surrounding environment [53]. The CPPA also defined "preservation of original form" as the basic rule in maintenance, protection and utilization, and Scenic Sites must follow this rule as well.

Scenic Sites, like other cultural heritage, are subject to a "rule of unchangeability in the status quo" in their surrounding environment and landscape for the "preservation of original form". To protect cultural heritage from activities that can affect its original form, various approaches are taken both within the Cultural Property Area, and Conservation Area of the Historic and Cultural Environment (CAHCE) that lies outside the Cultural Property Area. A Cultural Property Area is formed by the area occupied by designated cultural property, with the main purpose of preserving the original form of the designated cultural property. The CAHCE is a kind of buffer zone, an area $200 \mathrm{~m}$ to $500 \mathrm{~m}$ from the outer border of the Cultural Property Area. It is designed to protect the area from Alteration of Current State that can influence the conservation of cultural heritage. To plan on actions that can cause Alteration of Current State in Cultural Property Area and the CAHCE, such as development or construction works, one must report before taking action to either the Administrator of the CHA or the governor of the city or province to obtain permission. If the action is considered to be unsuitable for conserving cultural heritage in the Cultural Property Area or CAHCE, either the Administrator of CHA, or the governor of a city (or province), where the cultural heritage is located, can place limits in action through administrative orders onto the owner, administrator, + or the administrating group that planned on the action. The standard for making such administrative decisions to protect the sites is the protectable value of cultural heritage, such as historical, artistic, academic and landscape values. Scenic Sites are cultural heritage that give more consideration to landscape value in preserving its original form.

As mass tourism swept across Gacheon village after 2002 and indiscriminate development continued, the Cultural Heritage Administration of Korea (CHA) designated the village's rice terraces and the surrounding area as a Scenic Site in 2005. The CHA announced the designation as the 15th Scenic Site in October 2004, and described the purpose of the designation as follows:

The designation of the rice terraces as a Scenic Site is not only to conserve the collapsing local community and its rural cultural landscape from urbanization and industrialization, but also to take the advantage of it as a place which can provide experiences of traditional rural culture in the future [54]. 
This description implies that the administration was focusing on the practical usage of the site, rather than preservation of its original form.

Since 2000, Scenic Sites have gained stardom as tourist resources enough to prompt active excavations and research on their resources and expansion in the range of the concept, while resulting in an increased number of designations (95 of all 107 sites were designated between 2003 and 2014). The administrative system, however, has focused on increasing the number of designated sites with total dependence on top-down legal action, while restricting people's property rights without a consistent and objective framework for conservation [51,55,56]. Until 2001, Scenic Sites were designated for their natural landscape, which had to be preserved and maintained in biological and geological aspects. As in the case with Natural Monuments, therefore, there was not enough consideration for the living culture of residents. Rather than establishing a rational administrative system that directly benefitted residents, the focus was placed on the government's insistence on preservation through strict restriction of the CPPA. Such a focus caused inconvenience only to local residents living in or around designated sites. Another problem was that the objective standard for decisions to give permission and impose restrictions on Alteration of Current State based on the CPPA is vague. Most of the decisions were made by professionals, and especially, the simple judgements were made by a small number of experts commissioned by the CHA. Consequently, there is distrust in the reliability, consistency, and equity of the Scenic Site system. Rather than setting up borders that reflect regional characteristics and the local use of land, the designation is made by nothing but line-drawing on the map as an administrative task, and heavily focused on preserving primal landscape [57].

Conflicts over the systems and the collision of property rights caused by inconsiderate administration in relation to Scenic Sites were growing. It may be natural for land owners in designated areas to think of maximizing their private benefits by freely utilizing a property. As they have a strong desire to change and reform the surrounding landscape in any time and any way, they can be overcome by a victim mentality. They also worry about their property rights being violated, with a strong antagonism and a desire to receive compensation against governmental systems [58,59]. Likewise, though numerous villagers agree with the conservation of the rice terraces, they asserted that the administration should first take into consideration the expected decrease in the value of land and limits on property rights in land trading after the designation. In particular, local residents possessing plots in the village filed a civil complaint, while requesting the CHA to buy the entire site of the rice terraces (extracted from interviews with local residents and public officers of the CHA in 2011). The CHA, on the central government side, declined the request, while asking them to understand that the terraces have the value of the rural cultural landscape for the public good. They also declared that if the rice terraces were designated as a Scenic Site, it would be introduced to travel agencies over the country as a matter of course, and the benefit from the admission fees would be more effective than those from land trading. The CHA was aware that the rice terraces required continuous cultivation to maintain their multifaceted value, unlike other Scenic Sites. It was also worried that the value of the terrace would be damaged by indiscriminate development funded by outside capital (extracted from an interview with a public officer of the CHA in 2011). As the villagers persisted in filing a civil complaint about land trading, the administration has established a plan to nationalize the entire terrace in the village within five years after 2005. Unfortunately, the plan has fallen through due to the impact on Korea of the global financial crisis in 2008. 
Even in these circumstances, the Scenic Site policy has only focused on the physical aspects of scenic resources. It disregarded research on the awareness of local residents and local governments on designation and maintenance, and also on the value of making their participation in the process of decision-making. There is a lack of concern to take measures to draw up social agreements in Scenic Site policy, while causing deep conflicts. The most important element of Scenic Sites is the lifestyle of the people who live there, and interacted with, and created the landscape. There has not been enough consideration for the living culture of residents. Rather than establishing a rational administrative system that benefited residents, the focus has remained on the government's insistence on preservation through strict restriction of the CPPA, which in turn only causes inconvenience to local residents. In the past the CPPA enabled the national government to designate and restrict privately owned sites, but now social protest against it and checks from other laws are more powerful. At present it is almost impossible to designate Scenic Sites without the agreement of local residents or local government [50]. Scenic Sites have, until recently, been ignoring the intangible elements blended in such landscapes. In the case of Gacheon village and its rice terraces, the conservation only focused on the physical form of the rice terraces, without any understanding of traditional farming or the local community through which the knowledge is passed down. There are some Scenic Sites that are conserved when left alone, but there are also sites that require human intervention to be conserved, like these rice terraces. When dealing with Scenic Sites, comprehensive and systematic approaches are required in order to sustain the landscape and at the same time the specific life activities within it.

\section{Discussion: Implications for Sustaining Gacheon Village and Rice Terraces}

As seen from the conservation issues of Gacheon village, the future challenges for traditional rural landscapes will stem not only from sites themselves, but also from the contexts in which society embeds them. Moreover, as sites are now utilized in various ways, the conservation system requires comprehensive and systematic consideration of land planning, tourism, education, environment, and the local economy. Traditional rural landscapes, including Gacheon village, are landscape heritage that have been formed by various relationships between nature and culture, as well as between tangible and intangible factors. The main standard for judging heritage values, therefore, must be based on human-nature interactions. Even though existing policies for safeguarding rural landscapes in Korea have given the priorities to physical landscape, the true value of landscape is revealed when various contributory elements from the humanities are also considered, such as history, culture, religion, ideas, literature, art, and science. To correctly evaluate these intangible values, both natural and cultural values must be considered.

\subsection{Lessons from International Movements}

Recent international trends on cultural landscapes are moving away from an elite approach, which tends to focus on the exceptional and outstanding physical phenomena of landscape. Instead, they aim to accept relative and diverse values in order to understand landscapes as a complex body of values and to protect them. At the foundation, there is recognition of ideas on interactions between tangible and intangible aspects in place and rediscoveries of human-nature interactions. These interactions were considered to be separate; acknowledgement of attention by the local communities as the main body for 
passing down and utilizing heritage highlights public participation, while actively accepting local knowledge in order to sustainably safeguard heritage in democratic ways.

Two advisory bodies, ICOMOS and IUCN, raised an issue about how reference to values of minorities, indigenous and/or local, were made or obviously omitted [60]. Recognizing the issue arising from the applications to inscribe Tongariro National Park (New Zealand, 1993) and Uluru-Kata Tjuta (Australia, 1994) as World Heritage Cultural Landscapes, they argued that the State's Parties only rarely reflect on local cultures, the rights of these cultures, and prospective conflicts between these cultures and international efforts for protection [60]. In this regard, follow-up measures were made to the management and legal provisions of the World Heritage Convention. It became possible to nominate a site where it has:

Adequate legal and/or traditional protection and management mechanisms to ensure the conservation of the nominated cultural properties or cultural landscape. The existence of protecting legislation at the national, provincial, or municipal level and/or a well-established contractual or traditional protection as well as of adequate management and/or planning control mechanisms is therefore essential ... Assurances of the effective implementation of these laws and/or contractual and/or traditional protection as well as of these management mechanisms are also expected [61].

For the first time in the history of the convention, traditional management mechanisms and customary law from local cultures were considered acceptable forms of conservation of cultural landscape. In particular, the 2003 Convention for the Safeguard of the Intangible Heritage addressed the necessity of considering indigenous people whose practice, representations, expressions, knowledge, and skills are transmitted from generation to generation in non-material forms. These intangible values have been constantly recreated by local people in response to their environment, their interaction with nature and their history, and these inherent values provide them with a sense of identity and continuity. Conserving intangible values in cultural heritage encourages them to enrich cultural diversity and human creativity and, by extension, their human rights [62].

In Asia, in particular, non-material values are unarguably integral to recognizing the authentic meaning of the landscape. The Hoi An Protocols provide guidelines for conserving cultural landscape in an authentic way, while reflecting the often-heated debate between Western principles and Asian values. With its holistic view of heritage values seen through the lens of authenticity, and its relevance to notions of heritage in Asia, the Hoi An Protocols provide instructive regional guidelines to manage cultural landscapes in Asia. The document shares Western scholarly discourses, especially from the new cultural geographers' approaches, which aim to interpret or read the landscape within one's own cultural process. This can be seen in the way that the document attempts to draw up an Asian way of interpreting and managing landscape [63]. Taylor analyzed the Eastern perspective on cultural landscapes, and suggested that Asian people understand landscape where the spirit of place resides as much in the meaning and symbolism of places and their setting - intangible values — as it does in tangible physical fabric [64]. The Hoi An Protocols also place more emphasis on intangible values in cultural landscape, saying that they are integral for the effective conservation of authenticity. The document understands that cultural landscapes in Asia reflect organizing philosophies and perspectives of different cultures imbued with value systems, the traditional knowledge system and abstract framework: cosmology, 
geomancy and feng-shui, animism, and technological and economic systems [65]. The protocols emphasize conservation of not only the physical, human-made components of landscape, but also intangible aspects of landscape. That is because the tangible aspects we can see in landscape are not only inextricably linked to but also arise from the natural geography and environmental setting of their respective cultures, and serve as the setting for more intangible expressions of cultural traditions [64].

In line with this thinking, the recent operational guidelines for managing World Heritage Cultural Landscape recommend: "Be prepared in collaboration with and the full approval of local communities in order to reflect the full range of values represented in the landscape, both cultural and natural [15]." In the conservation of cultural landscapes, the full engagement of local communities is highly recommended, with encouragement to [66]:

- Foster the development of guidelines and principles of practice for the inclusion of consultative, community-based processes in the planning and management of heritage landscapes.

- Support the understanding and continuation of traditional practices in the stewardship of heritage landscapes.

- Recognize that multi-values are present in heritage landscapes and that multiple voices, including strong community engagement, need to be brought to their protection and management.

- Respect the living traditions and footprints of indigenous peoples that permeate the heritage landscape.

Owing to the increasing level of discourse in the heritage field, conservation has become a social process, by which to pursue the public interest and its quality of life. The process of conservation, therefore, requires new groups in order to make rational and balanced decisions rather than a single scientific deliberation from a small number of experts. These groups of ordinary people, of professionals from other fields, and of representatives of special interests, such as Non-Governmental Organizations (NGOs), arrive in the heritage field with their own criteria and their own values that often differ from those of conventional heritage specialists $[67,68]$. The expert group could probably claim that they were likely to make the most rational decision in these circumstances. The value of the stakeholder or public engagement is not that they enhance the rationality of decision-making, but that they do precisely the opposite; they insist on the importance of emotional, historical, associative and other "soft" qualities that temper hard rationalism.

\subsection{Current Endeavours to Safeguard and Sustain Gacheon Village and Rice Terraces}

Since 2000, the notions of intangible values and public participation have been the main subjects of heritage discourses in Korea. The value of heritage lies not only in their legacy content, but also in the psychological basis they provide for the identity and pride of people. The importance of conservation and safe utilization of heritage, therefore, has become a significant issue in Korean heritage policy [69]. Before the economic struggle around 2000, the CHA's policies focused on preserving the original fabric of cultural properties. However, after the CHA became a vice-minister level agency in 2004, the administration widened its coverage from its basic policy of safeguarding heritage to that of discovering and recreating heritage values in order to promote practical usage. 
When the CHA declared the General Plan for Conservation, Management, and Utilization of Cultural Heritage in 2002 [70], it indicated the direction of policies and strategies for the use of heritage. An amended guideline was issued in 2007, while setting up long-term plans to employ various policies in order to discover the inbuilt value of heritage and re-evaluate them from a modern prospective [71]. In 2011, CHA declared the Five-Year Plan for Conservation, Management, and Utilization of Cultural Heritage with substantial suggestions to maintain consistency and timeliness of the administration system for heritage policies. The five-year plan said that cultural heritage should be bursting with vitality, sustainable, and more familiar to people, so that it could be the centrepiece of Korea's cultural, state, and tourism resources [72].

Meanwhile, the government started to devise ways of engaging public participation in heritage policies. From 1998 to 2011, the number of items of state-designated heritage dramatically increased from 7315 to 11,413. CHA's budget for heritage also radically increased, about four times from 139 billion KRW (127 million USD) to 523 billion KRW (477 million USD). The workforce of the CHA increased from 541 to 857 in the same period. However, these developments were not enough to meet the increasing public demand for enjoying cultural heritage. As a result, the government sought to initiate public-private cooperation to sustain the proper use of cultural heritage, and the successful transfer of cultural heritage to the next generation. In November 2004, the CHA embarked on a "One Heritage, One Keeper" campaign to promote voluntary conservation, management, and utilization of cultural heritage to the public. In the campaign, individuals, families, and organizations were assigned the duty of constantly monitoring their areas' cultural heritage conservation status $[65,68]$. The Act on the National Trust of Cultural Heritages and National Environment Assets was passed in 2006 to support public-led administrative works to safeguard natural and cultural heritage. The National Trust of Korea (NTK) had been established in 2000 to manage valuable cultural resources by the public funds on the model of the UK National Trust. The Act on the National Trust was the result of the activity and endeavours of the NTK [73]. In 2007, Korea also enacted the Landscape Act. The Act defined the term landscape as "features composed of natural and artificial elements, lifestyles of residents, and so on, and featuring regional environmental characteristics." Therefore, it has functioned as a basic law with the purpose of contributing to making national and regional environments beautiful, pleasant, and featuring regional characteristics. The Landscape Act aims to provide a guideline for the systematic landscape management by providing for the preservation, management, and creation of various kinds of landscape resources. The act highlights grassroots participation and bottom-up policies in landscape planning and management with thorough consideration of local environment, economy, history, and culture in order to maintain and cultivate local identity.

As a part of this movement, Gacheon village has been managed by Trust Members (sponsored by Daraengi One Mind Sharing), who have paid 50,000 KRW (45 USD) in annual dues since 2007. It intends to secure stable investment funds from members for maintenance, management, and development of the rice terraces. It provides to regional specialties that have been produced on rice paddies, such as rice, garlic, and spinach, the compensation, being worth 40,000 KRW (37 USD), three times a year. As members can be supplied with reliable products at a low price, it is regarded as a win-win strategy. By holding a "One Heritage, One Keeper" campaign promoted by the CHA, the village successfully concluded a sponsorship agreement with Samsung Electro-mechanics Co., Ltd. of Pusan Workplace in 2007. As a result, it has been able to recruit 700 and 300 Trust members in 2007 and 2008, respectively. 
The local government of Namhae County selected Gacheon village as a flagship project for Village Corporation in 2010. The purpose of the Village Corporation project was to revitalize the local community through revenue-making businesses in order to provide incomes and jobs for local residents, and thereby contribute to local development. It had to be carried out by the local government and residents, because earlier farm village activation projects had not been able to reflect opinions of local community. The project aimed to solve local problems through healthy management led by indigenous people [74]. Gacheon village, by establishing Daraengi Farm Agricultural Association Corporation, came to manufacture and sell Makgeolli (rice wine) that has been produced by processing rice harvested on paddies. It also came to sell local food that had been harvested in the region after building a co-managed café in the village. It came to invest some part of the profits in social welfare services for the aged, and distribute the rest so that village residents could share them equally. In this way the local community fostered a business which reflected regional characteristics and protected the rice terraces, while raising the community's spirit.

In 2013, Conservation and Management Ordinance for the Rice Terraces of Gacheon Village was enacted so that the local community could actively participate in the activities of systematically conserving and sustainably managing the village and rice terraces. This local ordinance established a master plan for conservation and management of rice terraces, and also foundation of the Conservation Committee and financial and administrative supports. The committee consisted of local officials, community representatives, local residents, and tourism experts who deliberated on policy suggestions, restoration and maintenance, basic plans regarding conservation and management, support of conservation-related groups, and the provision of resident education programs. This was a pivotal step for residents, experts, and local and central governments in starting the cooperation in sustaining the rice terraces of the village.

On the basis of this local ordinance the residents founded the Rice Terrace Conservation Society into which all the residents participated. The purpose of the Conservation Society was to sustain the unique landscape of rice terraces by reviving abandoned rice paddies. First of all, the Conservation Society planted rice in the spring on the rice terraces $\left(22,212 \mathrm{~m}^{2}\right)$ that Namhae County had purchased from residents. After harvesting rice, they planted rape on the rice paddies. Here, it intended to make profits of 27 million KRW (25 thousand USD) through the DDP for Rice Paddy and DDP for Rural Landscape Conservation, provided by the central government. With these profits, the Conservation Society plans firstly to revive $50 \%$ of the rice terraces in urgent condition $\left(16,529 \mathrm{~m}^{2}\right)$, and then to carry out general farming activity. In addition, the Conservation Society is planning to make it possible to introduce farming machines by fostering hard footpaths of rice paddy with hardened red clay. Then, it is planning to reproduce conventional farming techniques after purchasing two working cows with a budget of 5 million KRW (4600 USD). By holding village rituals and festivals in relation to rice terraces and the local community, it is combining the use of the village as a tourism resource with that of traditional landscape heritage. For this purpose, the CHA has supported the actual expense of holding village rituals from 2013. It is expected that this voluntary conservation movement of the residents will be administratively supported by the local ordinance. Unfortunately, since May 2013, when the local ordinance was enacted, there has been no publication of clear results satisfying the goals of the Conservation Society. As rural landscape cannot be formed in a short period, the results of landscape 
management cannot be gained in a short time. Because it is difficult to gain results as compared to efforts, landscape management should be considered in a long-term perspective.

\section{Conclusions}

In the face of multifaceted threats to rural societies, since the early $1980 \mathrm{~s}$, there have been series of central and local administrative measures to revive the local community and to conserve its distinctive landscape of Gacheon village. However, these top-down and short-sighted landscape conservation and management strategies have limited the village to the creation of a one-off event place, which is isolated from indigenous people living in the landscape. Given that traditional rural landscapes are artifacts that have been formed by human culture in the natural environment, their tangible and intangible values should be rediscovered and explored. These values, then, should be conserved and transmitted in the context of a landscape that is being continually used, shaped, and changed. Here, by listening to multiple voices, recent international trends on sustaining cultural landscapes place great emphasis on understanding these multiple values that are presented in the landscape. It is, accordingly, suggested that strong community engagement in the landscape should be transmitted into conservation and management practices.

To conserve such traditional rural landscape as rice terraces for sustainable use while maintaining authentic values, research on history and traditional ways of enjoying the site are not only needed, but active consultative groups of stakeholders should also be formed to preserve the knowledge of local residents. These local residents have been supporting cultural and ecological diversity of the site, and using this knowledge in safeguarding the site. Such consultative groups must include representatives of the national and local government, land owners, local residents, and professionals with local and professional knowledge. They must run continuously for management and monitoring through a democratic process. It is extremely important to position the roles of each group clearly, and to build up connective systems and partnerships between the groups. It is necessary to establish clear and comprehensive systems to sustain the site, in cultural and ecological aspects, as well as in terms of the local economy. This rural landscape cannot be maintained by ignoring the lives of local residents, and by entertaining the eyes of tourists. A plan that allows both local residents and tourists to co-exist is required, by providing self-respect for local residents, and by informing tourists of the various tangible and intangible values of the landscape and also the features that make the site authentic and the responsibility of visitors to safeguard and sustain it.

Here, elite groups, such as the central government and professionals, must change the conventional attitude that dominates the top-down administration system. The role of central government should be limited to providing a framework to support local governments, authorities, and community in the preparation of detailed programs. The central government could generate the framework by the reinterpretation of international discourses: UNESCO's World Heritage Cultural Landscape, Hoi An Protocols, IUCN's Category V Protected Landscapes/Seascapes, and FAO's GIAHS. The central government also should adopt a well-modulated governance approach, which is balanced between "carrots, sticks, and sermons". It should be provided with incentives in the form of subsidies and grants or raising people's awareness to help the managers and owners of the sites to make sustainable plans on conservation and utilization. Here, a professional group can play the role of facilitator and negotiator, to 
help different groups to make decisions and to adjust conflicts during the decision process respectively, rather than taking the role of the final arbiter.

Rice terraces are resources that represent local identity, which also enhance regional brand values. Conservation and management of the site cannot focus only on the visible landscape; it has to be planned in ways that improve the lives of local residents. Innovative measures will bring the dual effect of developing a sustainable economy and securing the protection of landscape at the same time. The successful management of traditional rural landscapes can create sustainable local and regional development and models of sustainable development, while drawing on traditional practices of sustainable use of resources. Through such sustainable development, management of these cultural landscapes can play a great role in people's lives and secure more supporters, and ultimately contribute to a sustainable future.

\section{Acknowledgments}

All authors are grateful for the valuable insights and remarks by interviewees which were a great help for improving the paper. We thank Jan Woudstra for his help in setting research direction, and Colin Roth for proof-reading and editing the paper.

\section{Author Contributions}

The first author Hae-Joon Jung designed this research, conducted interviews, and wrote this paper. Je-Hun Ryu also wrote the paper with the contribution to the direction of the idea, and made detailed revisions. All authors have given approval to the final manuscript.

\section{Conflicts of Interest}

The authors declare no conflict of interest.

\section{References}

1. Plieninger, T.; Höchtl, F.; Spek, T. Traditional land-use and nature conservation in European rural landscapes. Environ. Sci. Policy 2006, 9, 317-321.

2. Seong, J.-I. A Study on Rural Landscape Management and Policy Directions; Korea Rual Economic Institute: Seoul, Korea, 2005.

3. Hartel, T.; Fischer, J.; Câmpeanu, C.; Milcu, A.I.; Hanspach, J.; Fazey, I. The importance of ecosystem services for rural inhabitants in a changing cultural landscape in Romania. Ecol. Soc. 2014, 19, Article 42.

4. Stockdale, A.; Barker, A. Sustainability and the multifunctional landscape: An assessment of approaches to planning and management in the Cairngorms National Park. Land Use Policy 2009, 26, 479-492.

5. Council of Europe. Explanatory Report on the European Landscape Convention; Council of Europe: Strasbourg, France, 2000.

6. Antrop, M. The concept of traditional landscapes as a base for landscape evaluation and planning. The example of flanders region. Landsc. Urban Plan. 1997, 38, 105-117. 
7. Wolrd Rural Landcapes: A Worldwide Intiative for Global Conservation and Management of Rural Landscapes. Available online: http://www.worldrurallandscapes.org/ (accessed on 2 February 2015).

8. OECD. Multifunctionality: Towards an Analytical Framework; Organisation for Economic Co-operation and Developmen: Paris, France, 2001.

9. Meeus, J.H.A.; Wijermans, M.P.; Vroom, M.J. Agricultural landscapes in Europe and their transformation. Landsc. Urban Plan. 1990, 18, 289-352.

10. Selman, P. Sustainable Landscape Planning: The Reconnection Agenda; Routledge: Oxon, UK, 2012.

11. Vanslembrouck, I.; Huylenbroeck, G.V. Landscape Amenities: Economic Assessment of Agricultural Landscapes; Springer: Dordrecht, The Netherlands, 2005.

12. Groening, G. The "landscape must become the law" or should it? Landsc. Res. 2007, 32, 595-612.

13. Rössler, M. World Heritage Cultural Landscapes. George Wright Forum 2000, 17, 27-34.

14. Déjeant-Pons, M. The European Landscape Convention. Landsc. Res. 2006, 31, 363-384.

15. Olwig, K.R. The practice of landscape "conventions" and the just landscape: The case of the European Landscape Convention. Landsc. Res. 2007, 32, 579-594.

16. UNESCO World Heritage Centre. Operational Guidelines for the Implementation of the World Heritage Convention; UNESCO World Heritage Centre: Paris, France, 2012.

17. Council of Europe. The European Landscape Convention; Council of Europe: Florence, Italy, 2000.

18. Phillips, A. Management Guidelines for IUCN Category V Protected Areas Protected Landscapes/Seascapes; IUCN: Gland, Swiss, 2002.

19. Farina, A. The cultural landscape as a model for the integration of ecology and economics. BioScience 2000, 50, 313-320.

20. Naveh, Z. From biodiversity to ecodiversity: A landscape-ecology approach to conservation and restoration. Restor. Ecol. 1994, 2, 180-189.

21. Naveh, Z. Ecological and cultural landscape restoration and the cultural evolution towards a post-industrial symbiosis between human society and nature. Restor. Ecol. 1998, 6, 135-143.

22. Lee, C.-S.; Yoo, Y.-H. Cultural landscape of Korea, its entity, changes and values evaluation from new paradigm. J. Ecol. Field Biol. 2001, 24, 323-332.

23. Antrop, M. From landscape research to landscape planning: Aspects of integration, education and application. In From Holistic Landscape Synthesis to Transdisciplinary Landscape Management; Tress, B., Tress, G., Fry, G., Opdam, P., Eds.; Springer: Dordrecht, The Netherlands, 2005; pp. $27-50$.

24. Ford, J.; Martinez, D. Traditional ecological knowledge, ecosystem science, and environmental management. Ecol. Appl. 2000, 10, 1249-1250.

25. Rodwell, D. Conservation and Sustainability in Historic Cities; Blackwell: Oxford, UK, 2007.

26. Jackson, J.B. Discovering the Vernacular Landscape; Yale University Press: London, UK, 1984.

27. South Gyeongsang Province, Pinterest. Available online: https://www.pinterest.com/gyeongnam/ (accessed on 10 January 2015).

28. CHA. 2005 Designation Report on Natural Monuments and Scenic Sites; Cultural Heritage Administration: Daejeon, Korea, 2006.

29. Kim, H.-R.; Shin, J.-S.; Lee, S.-J. The Analysis of Existing State of Architect in the Darangyi-village of Garchon in Namhae County. J. Korean Inst. Rural Archit. 2010, 12, 101-108.

30. Gyeongnam Local Statistics Office. The Story of Rice by Means of Statistics; Statistics Korea: Changwon, Korea, 2008. 
31. CHA. 2011 Survey of Scenic Site Resources in Korea by Types; Cultural Heritage Administration: Daejeon, Korea, 2011.

32. Kim, H.-B. Travelling for Korean Scenic Sites; Gimmyoung Publisher: Seoul, Korea, 2013.

33. Namhae County Office. Alteration of Current State for Refurbishment around Rice Terraces of Gacheon Village; Namhae County Office: Namhae, Korea, 2007.

34. Youn, K.-S.; Lee, C.-H.; Kim, H.-D.; Seo, W.-H.; Lee, J.-K. The present status and the preservation method of the rice terrace as Scenic Sites resources in Northeast Asia. J. Korean Inst. Tradit. Landsc. Archit. 2011, 29, 111-123.

35. KREI. Farm Income \& Management Stabilization, that Should be Approacjed Like This; Korea Rural Economic Institute: Seoul, Korea, 2012.

36. Statistics Yearbook of Namhae County. Available online: http://stat.namhae.go.kr/html/index.asp (accessed on 7 February 2015).

37. Korean Institute of Rural Architecture. Master Plan. of Conservation, Management and Utilization of Rice Terraces in Gacheon Village; Namehae County Office: Namhae, Korea, 2007.

38. Namhae County Office, Annual Statistics of Namhae County, Available online: http://stat.namhae.go.kr/html/index.asp (accessed on 5 February 2015).

39. Lee, S.-H.; Kim, Y.-P. A comparative study on the conservation of rice terraces as cultural landscape in Korean and Japanese rural areas. J. Korean Inst. For. Recreat. 2011, 15, 1-14.

40. Gyeongnam News. The Sucessful Conservation of Riece Terraces of Gacheon Village depneds on Competitiveness. Available online: http://www.knnews.co.kr/news/articleView.php?idxno= 1053653 (accessed on 2 January 2015).

41. Ministry of Agriculture, Food and Rural Affairs, Available online: http://www.mafra.go.kr/ (accessed on 19 January 2015).

42. Oh, H.-E.; Kim, Y.-G. A study on the social conflicts caused by landscape conservation of rural tourism villages. J. Rural. Tour. Res. 2004, 11, 58-73.

43. Lowenthal, D. Living with and looking at landscape. Landsc. Res. 2007, 32, 635-656.

44. Choi, Y.-S.; Lee, G.-O.; Kim, B.-G.; Jung, H.-D. Analysis on the ripple effects of the rural traditional theme village. Korean J. Policy Res. 2013, 13, 23-39.

45. Shun, J.-S. A Study on the Alternatives of Viewpoints for Making Agricultural Theme Village of Tradition. Unpublished Master Thesis, Gyeongsang National University, Jinju, Korea, 2006.

46. Korea Institute Vlauation. Development Strategy of Special Local Development Zone Policy by Performance Evaluation; Ministry of Knowledge Economy: Seoul, Korea, 2012.

47. Kim, S.-Y. Revitalization of Rural Tourism for Gacheon Village in Namehae County. In Symposium on Conservation and Utilization of Rice Terraces and Gacheon Village in Namhae County, Namhae County; Cultural Heritage Administration: Namhae, Korea, 2012; pp. 55-64.

48. Gyeongnam News. Indiscriminate Developments Destroys Local Environment. Available online: http://www.knnews.co.kr/news/articleView.php?idxno=1038430 (accessed on 27 December 2014).

49. South Gyeongsang Province Office, Gyeongnam Real Estate Information System, Available online: http://kras.gsnd.net/ (accessed on 19 February 2015).

50. Kim, C.-K. The Introduction of Cultural Property Protection Act; Dongbang Press: Seoul, Korea, 2004. 
51. Lee, Y.-Y.; Lee, J.-H.; Kim, H.-D.; Lee, J.-K. A study on the traditional industrial landscape valued as Scenic Site: With the focus on Daranginon, Dok-sal, saltern. J. Korean Inst. Tradit. Landsc. Archit. 2012, 30, 14-13.

52. Ryu, J.-H. The Management System and process of Scenic Sites as National Heritage. In Interdisciplinary Research on Scenic Site; National Research Institute of Cultural Heritage: Daejeon, Korea, 2012; pp. 131-167.

53. Cultural Heritage Administration. Cultural Heritage Charter. Available online: http://english.cha.go.kr/ english/about_new/charter.jsp?mc=EN_02_04 (accessed on 8 October 2014).

54. Kyunghyang Shinmun, Rice Terraces of Namhae County will be Cultural Heritage. Available online: http://news.khan.co.kr/kh_news/khan_art_view.html?code=960201\&artid= 200410181736141 (accessed on 12 October 2014).

55. Kim, H.-B. The Present and Task of Korean Scenic Sites. In Proceedings of the International Symposium on the Present and Future of the Scenic Sites, Daejeon, National Research Institute of Cultural Heritage: Daejeon, Korea, 30 October 2009; pp. 338-364.

56. Lee. W.-S. The present and future of Korea's Scenic Sites. In Proceedings of the International Symposium on the Present and Future of the Scenic Sites, National Research Institute of Cultural Heritage, Daejeon, Korea, 30 October 2009; pp. 292-320.

57. Jung, H.-J. Landscape as Heritage: Towards a Conservation Framework for Scenic Sites in Korea. Unpublished Doctoral Thesis, University of Sheffield, Sheffield, UK, 2015.

58. Rho, J.-H.; Shin, S.-S.; Huh, J.; Choi, J.-H.; Kim, J.-M.; Park, B.-J.; Jo, U.-Y. Study on the typification of influence investigation area of cultural properties. J. Korean Inst. Tradit. Landsc. Archit. 2009, 27, 21-30.

59. Choi, J.-H. Conservation and Management of Scenic Sites. In Interdisciplinary Eesearch on Scenic Site; National Research Institute of Cultural Heritage (NRICH): Daejeon, Korea, 2012; pp. 38-77.

60. UNESCO. Convention Concerning the Protection of the World Cultural and Natural Heritage; UNESCO: Christchurch, New Zealand, 2007.

61. UNESCO World Heritage Centre. Operational Guidelines for the Implementation of the World Heritage Convention; UNESCO World Heritage Centre: Paris, France, 1999.

62. UNESCO. Convention for the Safeguarding of the Intangible Cultural Heritage; UNESCO: Paris, France, 2003.

63. Lowenthal, D. European Landscape Transformations: The Rural Residue. In Understanding Ordinary Landscapes; Groth, P., Bressi, T.W., Eds.; Yale University Press: New Haven, CT, USA, 1997; pp. 180-188.

64. Taylor, K. Cultural landscapes and Asia: Reconciling international and Southeast Asian regional values. Landsc. Res. 2009, 34, 7-31.

65. Bangkok, U. Hoi An Protocols for Best Conservation Practice in Asia: Professional Guidelines for Assuring and Preserving the Authenticity of Heritage Sites in the Context of the Cultures of Asia; UNESCO Bangkok: Bangkok, Thailand, 2009.

66. ICOMOS. Natchitoches Declaration on Heritage Landscapes. In Proceedings of the US/ICOMOS 7th International Symposium, Natchitoches, LA, USA, 27 March 2004; ICOMOS: Natchitoches, LA, USA, 2004. 
67. Torre, M. Assessing the Values of Cultural Heritage; The Getty Conservation Institute: Los Angeles, CA, USA, 2002.

68. Lee, S.-J. Preliminary study on defining and assessing heritage values for establishing conservation principles. Munhwajae Korean J. Cult. Herit. Stud. 2011, 44, 154-171.

69. Cultural Heritage Administration (CHA). A Safeguarding System for Cultural Heritage in Korea: Focused on the Activities of Restoration, Transmission and Protection of Designated Cultural Properties; Ministry of Strategy and Finance: Seoul, Korea, 2012.

70. Cultural Heritage Administration (CHA). The General Plan. for Conservation, Management and Utilisation of Cultural Heritage; CHA: Daejeon, Korea, 2002.

71. Cultural Heritage Administration (CHA). Cultural Heritage 2011: Medium- and Long-term Vision for Heritage Policies; Cultural Heritage Administration: Daejeon, Korea, 2007.

72. Cultural Heritage Administration (CHA). The Five-Year Plan. for Conservation, Management and Utilisation of Cultural Heritage; Cultural Heritage Administration: Daejeon, Korea, 2012.

73. Yoon, S.-J. History and Conservation of Gardens in Korea. Unpublished Doctoral Thesis, University of Sheffield, Sheffield, UK, 2009.

74. Gyeongnam Social Enterprise. What is a Village Corporation? Available online: https://se.gndo.kr/ se/sub03/01.jsp (accessed on 5 February 2015).

(C) 2015 by the authors; licensee MDPI, Basel, Switzerland. This article is an open access article distributed under the terms and conditions of the Creative Commons Attribution license (http://creativecommons.org/licenses/by/4.0/). 